\title{
Antagonistic activity of endophytic bacteria isolated from weed plant against stem end rot pathogen of pitaya in Vietnam
}

The Anh Luu ${ }^{1,2}$, Quyet Tien Phi ${ }^{3}$, Thi Thu Hang Nguyen ${ }^{4}$, Mai Van Dinh ${ }^{4}$, Bich Ngoc Pham ${ }^{3}$ and Quang Trung Do ${ }^{1 *}$

\begin{abstract}
Background: Fungal stem end rot disease of pitaya caused by Alternaria alternata is one of the most destructive diseases in Binh Thuan province, Vietnam. This study aimed to assess the antagonistic effects of some endophytic bacteria isolated from the weed plant (Echinochloa colonum) against A. alternata.

Results: A total of 19 endophytic bacteria were isolated and 5 of them presented in vitro antagonistic activity against A. alternata. Of five, strain EC80 significantly inhibited the pathogenic growth with a mean inhibition diameter of $11.88 \pm 0.08 \mathrm{~mm}$, while the other four (C79, EC83, EC90, and EC97) showed a weak inhibition. Interestingly, the combination of EC79 and EC80 reduced more biomass of pathogenic fungi than the single one did. EC79 showed positive results for amylase, indole acetic acid (IAA), and biofilm production, whereas EC80 presented positive capabilities for IAA and biofilm production and a negative one for amylase production. In addition, the combined filtrate of EC79 and EC80 presented non-antifungal activity on biocontrol tests in vitro, indicating that bacteria cells played a role in defending against the pathogen. Moreover, both isolates EC79 and EC80 significantly increased seedling biomass than the control.
\end{abstract}

Conclusions: The results suggest that those two strains in combination had the potential to be used as a biocontrol agent against A. alternata. More studies should be done in the future to evaluate their efficiency under the field conditions.

Keywords: Alternaria alternata, Biocontrol, Bacterial antagonist, Echinochloa colonum

\section{Background}

Pitaya is one of the main fruity cultivars in Vietnam, which is native from Mexico and belongs to two species of the genus Hylocereus: $H$. undatus (white flesh, accounting for more than $95 \%$ of production) and $H$. costaricensis (red flesh, about $4.5 \%$ of production) (Hoa Nguyen Van et al. 2014). In recent years, the pest takes a part in decreasing productivity and the quality of products, especially the stem end rot diseases that are caused by the fungus, Alternaria sp. (Hoa Nguyen Van et al. 2014). Currently, the disease situation is happening very

\footnotetext{
*Correspondence: trungensinh@gmail.com

${ }^{1}$ Central Institute for Natural Resources and Environmental Studies, Vietnam Nation University Hanoi, 19 Le Thanh Tong, Hoan Kiem, Ha Noi, Vietnam Full list of author information is available at the end of the article
}

complicatedly, spreading rapidly on a large scale, and thriving in the rainy season. Use of plant protection chemicals derived from Aviso 350SC, Simolex 720WP, Manozeb 80WP to control pitaya stem end rot disease is relatively effective, but their residues in the product are the biggest barrier to pitaya export to some markets such as the European Union, the USA, and Japan. Therefore, research using microorganisms as a biological agent to control the disease is an emerging research direction to meet the requirements for safe products, for export and domestic consumption, and for contribution to limiting the chemical use in agricultural production.

In agroecosystems, weeds exist parallelly with crops and are well adapted to the environment and grow or reproduce aggressively in association with crops (Blanco 
2016). Echinochloa colonum is a weed plant that has a wide range of habitats such as cultivated areas, waste grounds, ditches, and fields. It forms an important association with 35 crops in more than 60 countries (Rao et al. 2007). Besides, E. colonum has a rapid growth, a great competitive ability, and a severe infestation leading to substantial crop yield reductions. This might be the result of endophytic bacterial associates. Endophytic bacteria living in the weeds could benefit their weed host in various ways such as the production of bioactive compounds or the generation of induced systemic resistance (Samad et al. 2017; Khan et al. 2020; De Hita et al. 2020). Some studies have been carried out to find these interesting bacteria and to search for their beneficial usage in crop production (Lafi et al. 2016, 2017; Khan et al. 2020). For example, the endophytic bacteria isolated from Echinochloa crusgalli can promote plant growth and especially can degrade monoaromatic compounds (phenol, toluene, and xylene) and diesel. Hence, the application of weed endophytic bacteria in the biocontrol of plant diseases for sustainable agriculture can be a very promising tool because of their short lifecycle and high selection of antagonistic form.

In Vietnam, although some commercial products are available, using antagonistic fungi, there are no studies that have reported the discovering of endophytic bacteria from weeds and their potential usage in sustainable crop production. Therefore, this study aimed to explore the antagonistic form of endophytic bacteria from the weed (E. colonum) on A. alternata, a casual of pitaya stem end rot disease in Vietnam.

\section{Methods}

\section{Isolation of endophytic bacteria from $E$. colonum}

The potential bacterial antagonists were isolated from the stems, roots, and leaves of healthy E. colonum collected from different locations of Binh Thuan province, Vietnam, during June 2019. The samples were immediately washed under tap water to remove dust and soil. The fragments were disinfected by successive treatment with ethanol $70 \%(1 \mathrm{~min})$ and exhaustively rinsed several times with sterilized distilled water. The fragments were then submitted in mercuric chloride $0.01 \%$ (available chlorine) for $5 \mathrm{~min}$ and then rinsed again with sterilized distilled water for 3 times. Aliquots of $0.1 \mathrm{ml}$ of the last wash water were inoculated onto the media plates of $L B$ (yeast extract $5 \mathrm{~g} / \mathrm{l}$, tryptone $10 \mathrm{~g} / \mathrm{l}, \mathrm{NaCl} 5 \mathrm{~g} / \mathrm{l}$, agar $15 \mathrm{~g} /$ l, $\mathrm{pH} 7.0-7.5)$ to check the effectiveness of the disinfection process. After the disinfection, samples were cut into fragments $(5 \times 5 \mathrm{~mm})$ and placed onto the LB plates for the isolation of bacteria. The sterile distilled water uninoculated on LB plates were done as respective controls. All the plates were incubated at $28^{\circ} \mathrm{C}$ for 7 days and observed daily for the growth of a different type of bacterial colonies. The observed colonies were picked up and subcultured on new LB plates several times by repeated streaking (Quadrant streaking) till single type and isolated colonies were obtained. The obtained pure cultures were inoculated onto LB slants. After overnight incubation at $28{ }^{\circ} \mathrm{C}$, they were stored at $4{ }^{\circ} \mathrm{C}$ till further use.

\section{Antagonist activity of bacterial isolates in vitro}

All isolated bacteria were tested for antifungal activity. On a sterile potato dextrose agar (PDA, potato infusion $200 \mathrm{~g} / \mathrm{l}$; dextrose $20 \mathrm{~g} / \mathrm{l}$; agar $15 \mathrm{~g} / \mathrm{l} ; \mathrm{pH}=7.0-7.3)$ plate, a cylinder of a $1-\mathrm{cm}^{2}$ fungal plug (A. alternata) was placed in the center and each bacterial isolate was inoculated using a sterile stick at a distance of $2.5 \mathrm{~cm}$ from the fungus. Then, the plates were incubated at $28^{\circ} \mathrm{C}$ for $72 \mathrm{~h}$. The control plate was inoculated with only phytopathogenic fungi. The strains that showed an inhibition of the fungal growth were selected and preserved. The inhibition of mycelial growth was observed after 5 or 7 days. The antimicrobial activity was determined by measuring the diameter of the zone of inhibition that is the mean of triplicates \pm SE of 3 replicates.

\section{Biocontrol of combined strains on A. alternata}

In addition, the inhibition of possible combinations of those bacteria against $A$. alternata was investigated. A separate experiment with the isolates' strains was carried out to indicate the occurrence of competition on LB. The bacteria were cultured individually overnight. The cultures were mixed by a 1:1 ratio and inoculated as described in the standard antagonism test. After 2 weeks of incubation, the bacterial colony development was observed, and the antagonism ability of the combination was also determined.

\section{Antifungal activity of extracellular filtrates}

The overnight culture of the isolated bacterium with antifungal activity was used and filtrated to obtain extracellular filtrates. Then, biocontrol assays were carried out with the supernatant. After that, the plate incubation was done at $28^{\circ} \mathrm{C}$ for $120 \mathrm{~h}$ and verified every $12 \mathrm{~h}$. The indicator for the antifungal activity of filtrate was the fungal growth inhibition.

\section{In vitro assay of antifungal isolates Amylase, IAA, and biofilm production}

Amylase detection The bacteria were inoculated in the LB agar containing $1 \%$ starch (Biobasic, Canada). The starch agar plates were incubated at $37^{\circ} \mathrm{C}$ for 2 days after which they were flooded with Lugol's iodine solution (iodine $0.2 \mathrm{~g}$, potassium iodide $0.4 \mathrm{~g}$, distilled water $100 \mathrm{ml}$ ) for $2 \mathrm{~min}$. The control experiment was also set 
up, using LB plates without the inducing substrate (starch). The plates were observed for a clear zone of hydrolyzed starch against a blue background of unhydrolyzed starch. The experiment was replicated thrice.

Detection of IAA Indole acetic acid production was evaluated in LB agar media supplemented with 1\% tryptophan (Shrivastava and Kumar 2011). The wells were made on the media plates by means of a sterile inverted 1 -ml tip. Then, $200 \mu \mathrm{l}$ of overnight grown culture was pipetted into each well and incubated at $30^{\circ} \mathrm{C}$ overnight. After that, using tissue paper to remove the cultures gently from the wells was done and $200 \mu \mathrm{l}$ of IAA reagent was added into the empty well. In the next 5-10 min, an appearance of the pink halo zone around wells means the IAA production and the halo zone was measured including the whole cavity.

Biofilm formation A total of antifungal isolates was subjected to biofilm detection methods described by Christensen et al. (1995). A loopful of test organisms was inoculated in $10 \mathrm{ml}$ of LB in test tubes. The tubes were incubated at $37^{\circ} \mathrm{C}$ for $24 \mathrm{~h}$. After incubation, tubes were decanted and washed with phosphate-buffered saline ( $\mathrm{pH} 7.3)$ and dried. Tubes were then stained by crystal violet $(0.1 \%)$. The excess stain was washed by deionized water. Tubes were dried in an inverted position. The scoring for the tube method was done according to the results of the control strains. Biofilm formation was considered positive when a visible film lined the wall and the bottom of the tube. The amount of biofilm formed was scored as 1-weak/none, 2-moderate, and 3-high/strong. The experiment was performed in triplicate and repeated three times.

\section{Greenhouse experiment}

Pitaya seeds were surface sterilized by $2 \%$ sodium hypochlorite for $2 \mathrm{~min}$, rinsed thoroughly in sterile distilled water (SDW), and let dry on sterile discs of Whatman filter paper placed inside Petri dishes. Covering the pitaya seeds with the antagonistic bacterial suspensions $\left(10^{8} \mathrm{CFU} \mathrm{ml}{ }^{-1}\right)$ was carried out and then the bacterized seeds were incubated at $28^{\circ} \mathrm{C}$ for $72 \mathrm{~h}$ before sowing. In parallel, a mixture that included equal parts of peat, sand, and field soil was prepared and autoclaved twice for $20 \mathrm{~min}$ at $120^{\circ} \mathrm{C}$ with $24 \mathrm{~h}$ between autoclavings. Plastic pots $(6 \times 6 \times 5.5 \mathrm{~cm})$ were filled by a sterile substrate. The bacterized seeds were added $1 \mathrm{ml}$ of bacterial suspensions before covered with soil. For negative control, seeds were treated with SDW instead of the bacterial suspension. Pots containing the treated seeds were placed in the greenhouse according to a completely randomized block experimental design. For each treatment, 15 pots each containing 3 seeds were used. All treatments were designed in completely randomized experiments and 15 replicates for each treatment. Plant growth parameters were recorded 45 days after sowing, using parameters as follows: percentage of seed germination, seedling height, and the fresh and dry weight of shoots. The experiment was repeated once.

\section{Statistical analyses}

Data analysis was done with significance $(P<0.05)$ of treatment effects using one-way ANOVA, followed by post hoc comparisons (Tukey's HSD). Plant growth promoting activity of endophytic bacteria was determined by calculating the percentage increases in seed germination and plant growth parameters. The significance of the results was determined by Duncan's tests.

\section{Results}

Isolation of bacterial endophytes

A total of 19 endophytic bacteria were isolated from $E$. colonum collected at different locations of Binh Thuan province, Vietnam, during June 2019. The number of isolates recovered was 6 from roots, which represents 31.58\% of the total, 5 from stems (26.31\%), 8 from leaves (52.11\%). All 19 isolates were investigated for their antagonistic activity against the pitaya fungal pathogens $A$. alternata. The screening method for this study is based on growth inhibition of at least one of the assayed pathogen; only 5 isolates $(26.31 \%)$ with inhibiting effects of the pathogenic fungi in vitro were selected and their inhibited ability was found to be different when grown in the presence of the pathogenic fungi as well (Table 1). Among 5 bacteria with antimicrobial activity, strain EC80 showed a significant inhibition of pathogenic growth with a mean inhibition diameter of $11.88 \pm 0.08 \mathrm{~mm}$. The other strains including EC79, EC83, EC90, and EC97 presented weak inhibition effects on the mycelial growth of A. alternata, with mean inhibition diameter of $2.17 \pm 0.12,2.11 \pm 0.14$, $2.21 \pm 0.10$, and $1.99 \pm 0.13 \mathrm{~mm}$, respectively (Table 1).

In addition, the synergism of these antagonistic bacteria was also investigated. The results showed that the bacterial combination of EC79 and EC80 significantly inhibited the fungal growth and the inhibition was much stronger than that by the individual strains (Fig. 1). As shown in the figure, the combination of EC80 with E79 presented a dramatic inhibition of mycelial growth with $(15.12 \pm 0.41 \mathrm{~mm})$ (illustrated in Fig. 2), while other combinations of EC80 showed less with a mean diameter of inhibition zone ranging from $11.21 \pm 0.31$ to $12.11 \pm$ $0.19 \mathrm{~mm}$. The rest of the combined formula showed no improvement in inhibiting fungal growth.

To determine the effective part of the combined bacterial culture of EC79 and EC80, the supernatant was collected and tested for antifungal activities. The results showed that the supernatant presented non-antifungal 
Table 1 In vitro inhibition of growth of Alternaria alternata by single bacterial antagonists on PDA medium

\begin{tabular}{|c|c|c|}
\hline Strains & Mean diameter of inhibition zone $(\mathrm{mm})^{\mathrm{a}}$ & Degree of antagonism ${ }^{k}$ \\
\hline EC79 & $1.17 \pm 0.12^{b}$ & + \\
\hline EC80 & $11.88 \pm 0.08^{\mathrm{a}}$ & +++ \\
\hline EC83 & $2.11 \pm 0.14^{b}$ & + \\
\hline EC90 & $2.21 \pm 0.10^{b}$ & + \\
\hline EC97 & $1.99 \pm 0.13^{b}$ & + \\
\hline A. alternata + sterile distilled water & & - \\
\hline
\end{tabular}

${ }^{a}$ Values in the same column with the same letter(s) are not significantly different as determined by the LSD test $(P=0.01)$

bWeak "+" (1-5.99 mm), moderate "++" (6-10.99 mm), strong " +++ " (11-20 mm), inhibition effects on the growth of the pathogen

inhibition indicating that cells played vital roles in the inhibition of the disease (Fig. 2).

\section{Amylase, IAA, and biofilm production}

These two bacteria strains have also been investigated for amylase, IAA, and biofilm production. The results are summarized in Table 2. As shown in the table, EC79 produced amylase, IAA, and biofilm, while EC80 had the ability to the production of IAA and biofilm but did not have amylase activity.

Out of the two tested bacteria, only EC79 strain produced a clear halo zone on LB medium supplemented with $1 \%$ of starch when flooding with Lugol's solution, indicating amylase production. In addition, both strains, EC79 and EC80, possessed the ability to produce IAA, but EC79 produce IAA stronger than EC80 that was proved by the pink color observed. The results also presented the dark violet color on the Eppendorf wall meaning both strains have the ability in biofilm formation.

\section{Evaluation of plant growth promotion activity of endophytic bacteria}

All strains had positive effects on the germination of pitaya seeds. Bacterized seeds started to germinate early.



Fig. 1 Effect of co-culturing of five endophytic bacterial strains on fungal growth of Alternaria alternata. Fungal growth data are given for PDA agar plates inoculated with single bacterial strains and mixtures of these strains. Error bars denote standard deviations (three replicates). Different letters indicate significant differences $(P<$ 0.05) between treatments
The percentage of germinated seeds was greater than in the controls in vivo (Table 3). EC79 was the most active one: at 10 days after bacterization, more than $82 \%$ of the seeds were germinated as opposed to $53 \%$ of the controls. After 15 days, the germination rate of EC70 treated seeds reached $100 \%$, while this ratio of EC80-treated seeds was $77.7 \%$. The seeds treated by SDW got the least effective in vivo with a germination rate of $75.5 \%$.

Bacterized pitaya plants had increased growth parameters in greenhouse trials (Table 4 and Fig. 3). As shown in the table, endophytic bacteria particularly improved the shoot mass of plants since mean fresh and dry weights increased. EC79 strain was the most effective strain.

Their activity is illustrated in Fig. 3, where the results are presented as proportional (\%) increases in the percentage of plant growth parameters. These two bacterial strains produced marked increases in whole plant dry weights in vivo: EC79 increased shoot dry weight of (31.25\%), which was higher than the parameters of seeds bacterized with EC80 (20\%).

\section{Discussion}

Using biological control in pests and disease management for sustainable agriculture is a safer alternative method for the replacement of chemical pesticides, which are often deposited in soils and accumulated in plants (Nogórska et al. 2007; Khan et al. 2020; De Hita et al. 2020). Among biological sources, microorganisms have been used as a biocontrol agent and endophytic bacteria were reported as an emerging source contributing to the suppression or inhibition of the phytopathogenic growth (Raaijmakers et al. 2002). In this study, endophytic bacteria were isolated from the weed (E. colonum) to explore their potential as a biological agent in the integrated management of stem end rot caused by $A$. alternata.

The results showed that of the 19 endophytic bacteria isolated, only 5 presented antifungal activity over the studied fungi through diffusible substances in agar. However, the extracellular filtrates collected from these same microorganisms showed non-antifungal activity. Previous studies have proved that the bacteria can 

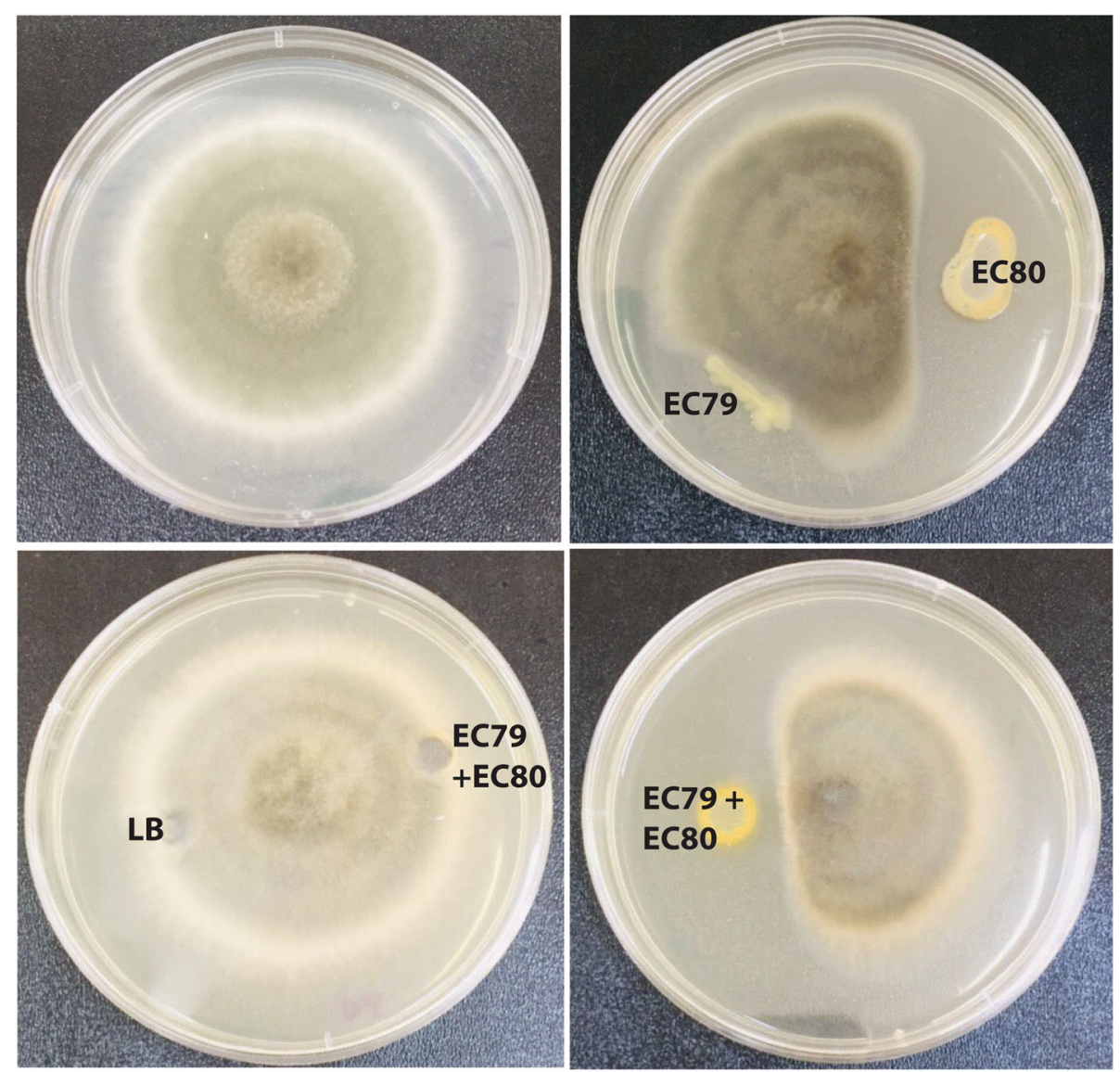

Fig. 2 Co-culturing of two endophytic bacterial strains on fungal growth of Alternaria alternata. Up-left panel: A. alternata on PDA media; up-right panel: antagonistic assay of EC79 and EC80 on A. alternata on PDA media; down-left panel: antagonistic assay of combined EC79 and EC80 on A. alternata on PDA media; down-right panel: antagonistic assay of filtrates of EC79 and EC80 on A. alternata on PDA media

inhibit the fungal growth by producing bioactive compounds such as extracellular lytic enzymes, siderophores, salicylic acid, antibiotics, and volatile metabolites, such as hydrogen cyanide (Kishore et al. 2005; Afsharmanesh et al. 2006; Imran et al. 2019; Khan et al. 2020; De Hita et al. 2020). In this study, the results indicated that EC79 produced amylase that might play roles in inhibiting fungal growth. In addition, it was possible that the isolates in this study generated antifungal volatile compounds that were lost in the process of obtaining the filtrates. Moreover, the results from the antagonistic assay of filtrate suggest the presence of bacteria was necessary for the substances responsible for the inhibition and could be associated with the bacterial envelopes.

Table 2 Production of amylase and IAA and biofilm formation of bacterial strains

\begin{tabular}{llll}
\hline Isolate & Amylase & IAA & Biofilm formation \\
\hline EC79 & ++ & +++ & +++ \\
EC80 & - & + & +++ \\
\hline
\end{tabular}

In vitro antagonism assays were normally carried out to screen bacterial strains contributing to the natural inhibition of plant pathogenic fungi. In this study, the results were also shown that strains including EC79, EC83, EC90, and EC97 were ineffective singly against $A$. alternata; however, when it was combined 1:1 with the strongest antagonistic bacteria (EC80 strain), an improved inhibition ratio was recorded for EC79 + EC80 combination. This indicated that the natural existence of synergic activity between

Table 3 Mean percentage of germinated seeds at 5, 10, and 15 days after bacterization with endophytic strains in vivo

\begin{tabular}{llll}
\hline $\begin{array}{l}\text { Endophytic } \\
\text { bacteria }^{\mathrm{a}}\end{array}$ & \multicolumn{3}{l}{ In vivo (bacterial suspension) } \\
\cline { 2 - 4 } $\mathbf{5}$ days & $\mathbf{1 0}$ days & $\mathbf{1 5}$ days \\
\hline EC79 & $4.4 c^{\mathrm{b}}$ & $82.2^{\mathrm{b}}$ & $100^{\mathrm{b}}$ \\
EC80 & $2.2^{\mathrm{b}}$ & $55.5^{\mathrm{a}}$ & $77.7^{\mathrm{a}}$ \\
Control & $0^{\mathrm{a}}$ & $53.3^{\mathrm{a}}$ & $75.5^{\mathrm{a}}$ \\
\hline
\end{tabular}

${ }^{\mathrm{a} B a c t e r i a}$ strains, control $=\mathrm{SDW}=$ sterile distilled water

${ }^{b}$ Data followed by the same letters are not statistically different according to the Duncan test $(P<0.01)$ 
Table 4 Mean parameters of in vivo pitaya seedlings treated with different endophytic bacterial strains

\begin{tabular}{llll}
\hline${\text { Endophytic } \text { bacteria }^{a}}^{\text {EC79 }}$ & Seedling length $(\mathbf{c m})$ & Fresh weight $\mathbf{( g )}$ & Dry weight $(\mathbf{g})$ \\
\hline EC80 & $3.23 \mathrm{a}^{\mathrm{b}}$ & $0.64 \mathrm{a}$ & $0.04 \mathrm{a}$ \\
Control & $2.80 \mathrm{ab}$ & $0.55 \mathrm{ab}$ & $0.03 \mathrm{a}$ \\
\hline
\end{tabular}

${ }^{\mathrm{a}}$ Bacteria strains; control $=\mathrm{SDW}=$ sterile distilled water

${ }^{b}$ Data followed by the same letters are not statistically different according to the Duncan test $(P<0.01)$

the antagonist strains, even between the antagonist and non-antagonist strains (Shen et al. 2020) or between non-antagonist strains (de Boer et al. 2007). The present study showed also that the combination of EC79 + EC80 strains generated a better antagonist for A. alternata clarifying the microbial synergism in inhibiting the pathogenic fungi, which is consistent with previous researches on combinations of biocontrol agents (Guetsky et al. 2007; Xu et al. 2010; Shen et al. 2020). The possible explanation for the extra reduction of fungal biomass production was that during the synergism, bacteria may support another one by producing metabolic products, which may be beneficial to another or show complementary advantages (Artursson et al. 2006; Kumar et al. 2016). All in all, the present study indicated that endophytic bacteria isolated did not show an antagonistic activity of one isolate toward others.

Interestingly, both the two tested bacteria produced IAA that was reported playing a role in the interaction between plant pathogens and host (Kunkel and Harper 2018). Although the single strain EC79 had earlier shown a limited effect on biocontrol of A. alternata, it presented the highest IAA yield and enhanced plant growth parameters. These results suggested EC79 may have a special function in promoting plant growth and enhancing resistance to disease when combined with other antagonistic strains. These results were consistent with previous reports (Ganesan et al. 2007; Asril et al. 2014;
Suárez-Moreno et al. 2019; Fan et al. 2020). Presumably, combining microorganisms with different antagonistic ability could improve not only the reduction of pathogens but also the plant performance.

It is well known that the biocontrol process mediated by plant growth-promoting rhizobacteria (PGPR) relies on multiple mechanisms (Khan et al. 2020; De Hita et al. 2020). Among those, biofilm formation played an important role in the ability of PGPR to control plant diseases (Rafique et al. 2015; Fu et al. 2020). Obtained results showed the biofilm formation of these two bacteria that indicated the vital roles of bacteria cells in the inhibition of the disease. They may colonize in the seedlings forming biofilm and consistently exerting their antagonistic effect, which also required further study to validate. It is said that successful colonization plays an important role in the function of antagonistic bacteria on the plant (Rafique et al. 2015) and bacterial biofilms can ensure the long-term colonization of a host (Fu et al. 2020). However, the plant was reported as the host of massive amounts of microbes (Lamont et al. 2018; Chen et al. 2018), which might prevent the colonization and reduce the function of antagonistic bacteria. Therefore, an important requirement for maximizing the antagonistic efficacy of the bacteria was to optimize the inoculation conditions that promoted biofilm formation and improved bacterial antagonist.
A

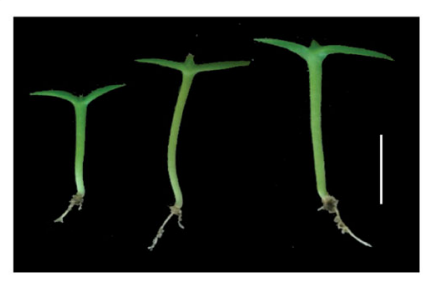

B

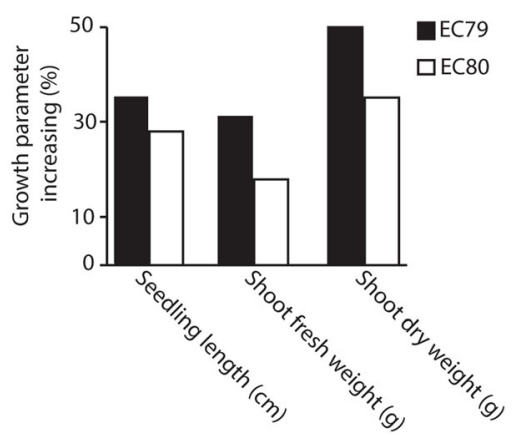

Fig. 3 Endophytic bacteria improve the growth parameters of pitaya plants in greenhouse trials. a Presentative for increasing the seedling length. b Improvement of plant biomass. Mean percentage increases of in vivo plant growth parameters for the most effective endophytic bacterial strains assessed in this study; scale bar $1 \mathrm{~cm}$ 


\section{Conclusions}

Pitaya in Vietnam's agriculture faces many challenges such as the stem end rot disease caused by A. alternata. Nineteen endophytic bacteria were isolated from the weed (E. colonum). Five of them could differently inhibit the mycelial growth of $A$. alternata. Strain EC80 exhibited the strongest inhibition, while a weak inhibition was observed by EC79, EC83, EC90, and EC97. The results also presented a combination of EC79 and EC80 had significant improvement in reducing biomass pathogenic fungi. In greenhouse experiments, the EC79 and EC80 improved the seedling biomass. Hence, these bacteria are potentially very useful for applications in the areas of agronomy and should be further explored in the near future.

\section{Abbreviations}

IAA: Indole-3-acetic acid; LB: Luria broth; PDA: Potato dextrose agar; SDW: Sterile distilled water; SE: Standard deviation

\section{Acknowledgements}

Not applicable.

\begin{abstract}
Authors' contributions
LTA and PQT conceptualized the project and carried out in vitro and biochemical experiments, data analyses, and original manuscript draft preparation. NTTH isolated endophytic bacteria. DMV and PBN carried out greenhouse experiments. DQT was involved in the conceptualization, supervision, final interpretation of data, and editing of the manuscript. All authors have read and approved the manuscript.
\end{abstract}

\section{Funding}

This research is funded by the Graduate University of Science and Technology under grant number GUST.STS.ET2020-SH05. The Graduate University of Science and Technology provided fund for collecting samples and buying chemicals for experiments and supported experimental facilities to carry out experiments.

\section{Availability of data and materials}

All data are available in the manuscript.

\section{Ethics approval and consent to participate}

Not applicable.

\section{Consent for publication}

Not applicable.

\section{Competing interests}

The authors declare that they have no competing interests.

\section{Author details}

${ }^{1}$ Central Institute for Natural Resources and Environmental Studies, Vietnam Nation University Hanoi, 19 Le Thanh Tong, Hoan Kiem, Ha Noi, Vietnam. ${ }^{2}$ Graduate University of Science and Technology, Vietnam Academy of Science and Technology, 18 Hoang Quoc Viet, Cau Giay, Ha Noi, Vietnam. ${ }^{3}$ Institute of Biotechnology, Vietnam Academy of Science and Technology, 18 Hoang Quoc Viet, Cau Giay, Ha Noi, Vietnam. ${ }^{4}$ Vietnam National University of Forestry, Xuan Mai, Chuong My, Ha Noi, Vietnam.

Received: 29 October 2020 Accepted: 8 January 2021

Published online: 13 January 2021

\section{References}

Afsharmanesh H, Ahmadzadeh M, Sharifi-Tehrani A (2006) Biocontrol of Rhizoctonia solani, the causal agent of bean damping-off by fluorescent pseudomonads. Commun Agric Appl Biol Sci 71(3 Pt B):1021-1029
Artursson V, Finlay RD, Jansson JK (2006) Interactions between arbuscular mycorrhizal fungi and bacteria and their potential for stimulating plant growth. Environ Microbiol 8(1):1-10. https://doi.org/10.1111/j.1462-2920.2005. 00942.x

Asril M, Suryanto D, Munir E, Kardhinata E (2014) Assay of antagonistic bacteria of single isolate and combination to control seedling-off in chili seed caused by Fusarium oxysporum. J Pure Appl Microbiol 8:645-650

Blanco Y (2016) Review The role of weeds as a component of biodiversity in agroecosystems. Cultivos Trop 37(4):34-56. https://doi.org/10.13140/RG.2.2. 10964.19844

Chen HM, Wu HX, Yan B, Zhao HG, Liu FH et al (2018) Core microbiome of medicinal plant Salvia miltiorrhiza seed: a rich reservoir of beneficial microbes for secondary metabolism. Int J Mol Sci 19(3):672. https://doi.org/10.3390/ ijms 19030672

Christensen GD, Simpson WA, Younger JJ, Baddour LM, Barrett FF, Melton DM, Beachey EH (1995) Adherence of coagulase negative Staphylococci to plastic tissue cultures: a quantitative model for the adherence of Staphylococci to medical devices. J Clin Microbiol 22:996-1006. https://doi.org/10.1128/JCM. 22.6.996-1006.1985

de Boer W, Wagenaar AM, Gunnewiek P, Veen J (2007) In vitro suppression of fungi caused by combinations of apparently non-antagonistic soil bacteria. FEMS Microbiol Ecol 59(1):177-185. https://doi.org/10.1111/j.1574-6941.2006. 00197.x

De Hita D, Fuentes M, Zamarreño AM, Ruiz Y, Garcia-Mina JM (2020) Culturable bacterial endophytes from sedimentary humic acid-treated plants. Front Plant Sci 11:837. https://doi.org/10.3389/fpls.2020.00837

Fan D, Subramanian S, Smith DL (2020) Plant endophytes promote growth and alleviate salt stress in Arabidopsis thaliana. Sci Rep 10:1274. https://doi.org/10. 1038/s41598-020-69713-5

Fu H, Chen F, Liu W, Kong W, Wang C, Fang X, Ye J (2020) Adding nutrients to the biocontrol strain JK-SH007 promotes biofilm formation and improves resistance to stress. AMB Express 10(1):32. https://doi.org/10.1186/s13568-0190929-8

Ganesan S, Kuppusamy RG, Sekar R (2007) Integrated management of stem rot disease (Sclerotium rolfsii) of groundnut (Arachishypogaea L.) using Rhizobium and Trichoderma harzianum (ITCC - 4572). Turk J Agric For 31(2):103-108

Guetsky R, Shtienberg D, Elad Y, Dinoor A (2007) Combining biocontrol agents to reduce the variability of biological control. Phytopathology 91(7):621-627. https://doi.org/10.1094/PHYTO.2001.91.7.621

Imran A, Zabta KS, Shomaila S, Shaheen S (2019) Plant beneficial endophytic bacteria: mechanisms, diversity, host range and genetic determinants. Microbiol Res 221:36-49. https://doi.org/10.1016/j.micres.2019.02.001

Khan M, Gao J, Chen X, Zhang M, Yang F, Du Y, Moe T, Munir I, Jing X, Zhang X (2020) Isolation and characterization of plant growth-promoting endophytic bacteria Paenibacillus polymyxa SK1 from Lilium lancifolium. Biomed Res Int 2020:1-17. https://doi.org/10.1155/2020/8650957

Kishore GK, Pande S, Podile AR (2005) Biological control of collar rot disease with broad-spectrum antifungal bacteria associated with groundnut. Can J Microbiol 51:123-132. https://doi.org/10.1139/W04-119

Kumar M, Mishra S, Dixit V, Kumar M, Agarwal L (2016) Synergistic effect of Pseudomonas putida and Bacillus amyloliquefaciens ameliorates drought stress in chickpea (Cicer arietinum L.). Plant Signal Behav 11(1):e1071004. https://doi. org/10.1080/15592324.2015.1071004

Kunkel BN, Harper CP (2018) The roles of auxin during interactions between bacterial plant pathogens and their hosts. J Exp Bot 69(2):245-254. https:// doi.org/10.1093/jxb/erx447

Lafi FF, Alam I, Bisseling T, Geurts R, Bajic VB, Saad MM (2017) Draft genome sequence of the plant growth-promoting rhizobacterium acinetobacter radioresistens strain SA188 isolated from the desert plant Indigofera argentea. Genome Announcements 5(9):e01708-e01716. https://doi.org/10.1128/ genomeA.01708-16

Lafi FF, Bokhari A, Alam I, Bajic VB, Hirt H, Saad MM (2016) Draft genome sequence of the plant growth-promoting Cupriavidus gilardii strain JZ4 isolated from the desert plant Tribulus terrestris. Genome Announcements 4(4):e00678-e00616. https://doi.org/10.1128/genomeA.00678-16

Lamont GJ, Praslickova D, Ricci E, Subramanian S, Smith DL (2018) Plant growthpromoting rhizobacteria: context, mechanisms of action, and roadmap to commercialization of bio-stimulants for sustainable agriculture. Front Plant Sci 9:1473. https://doi.org/10.3389/fpls.2018.01473

Nogórska K, Bikowski M, Obuchowski M (2007) Multicellular behavior and production of a wide variety of toxic substances support usage of Bacillus 
subtilis as a powerful biocontrol agent. Acta Biochim Pol 54(3):495-508. https://doi.org/10.18388/abp.2007_3224

Raaijmakers JM, Vlami M, de Souza JT (2002) Antibiotic production by bacterial biocontrol agents. Antonie Van Leeuwenhoek 81:537-547. https://doi.org/10. 1023/A:1020501420831

Rafique M, Hayat K, Mukhtar T, Amna KA, Afridi MS, Hussain T, Sultan T, Munis MFH, Imran M, Chaudhary HJ (2015) Bacterial biofilm formation and its role against agricultural pathogens. In: Méndez Vilas A (ed) The Battle against microbial pathogens: basic science, technological advances and educational programs. Formatex Research Center, Spain, pp 373-382

Rao AN, Johnson DE, Sivaprasad B, Ladha JK, Mortimer AM (2007) Weed management in direct-seeded rice. Adv Agron 93:153-255. https://doi.org/10. 1016/S0065-2113(06)93004-1

Samad A, Antonielli L, Sessitsch A, Compant A, Trognitz F (2017) Comparative genome analysis of the vineyard weed endophyte Pseudomonas viridiflava CDRTc14 showing selective herbicidal activity. Sci Rep 7:17336. https://doi. org/10.1038/s41598-017-16495-y

Shen YC, Korkor NL, Xiao R, Pu Q, Hu M, Zhang SS, Kong DD, Zeng G, Hu XF (2020) Antagonistic activity of combined bacteria strains against southern blight pathogen of Dendrobium officinale. Biol Control 151:104291. https:// doi.org/10.1016/j.biocontrol.2020.104291

Shrivastava UP, Kumar A (2011) A simple and rapid plate assay for the screening of indole-3-acetic acid (IAA) producing microorganisms. Int J Appl Biol Pharm Technol 2:120-123

Suárez-Moreno ZR, Vinchira-Villarraga DM, Vergara-Morales DI, Castellanos L, Ramos FA, Guanaccia C, Degrassi G, Venturi V, Moreno-Sarmiento N (2019) Plant-growth promotion and biocontrol properties of three Streptomyces spp. isolates to control bacterial rice pathogens. Frontiers in. Microbiology 10:290. https://doi.org/10.3389/fmicb.2019.00290

Van HN, Hieu NT, Hanh TTM, Uyen DTK, Dien LQ (2014) Emerging infectious diseases and insect pests of dragon fruit, passion fruit, citrus, longan. Proc. In: Workshop on Increasing Production and Market Access for Tropical Fruit in Southeast Asia. SOFRI, Viet Nam, pp 87-100 (in Vietnamese with an abstract in English)

Xu X, Robinson J, Jeger M, Jeffries P (2010) Using combinations of biocontrol agents to control Botrytis cinerea on strawberry leaves under fluctuating temperatures. Biocontrol Sci Tech 20(4):359-373. https://doi.org/10.1080/ 09583150903528114

\section{Publisher's Note}

Springer Nature remains neutral with regard to jurisdictional claims in published maps and institutional affiliations.

\section{Submit your manuscript to a SpringerOpen ${ }^{\circ}$ journal and benefit from:}

- Convenient online submission

- Rigorous peer review

- Open access: articles freely available online

- High visibility within the field

- Retaining the copyright to your article

Submit your next manuscript at $\boldsymbol{\nabla}$ springeropen.com 